\title{
Characterization of Infections Associated with Health Care in Pediatrics Bogotá 2017
}

\author{
Maria C Mejía ${ }^{1 *}$, Luis G Piñeros², Anibal A Teherán ${ }^{3}$ and Luis M Pombo ${ }^{4}$ \\ ${ }^{1}$ Physician, Epidemiologist, COMPLEXUS Research Group. Corpas University, Colombia \\ ${ }^{2}$ Physician, Family Medicine Specialist, GIFVTA Research Group. Research Group. Corpas University, Colombia \\ ${ }^{3}$ Physician, Epidemiologist, COMPLEXUS Research Group. Corpas University, Colombia \\ ${ }^{4}$ CI GIFVTA Research Group. Corpas University, Colombia
}

Submission: August 11, 2018; Published: October 15, 2018

*Corresponding author: Maria C Mejía, Physician, Epidemiologist, COMPLEXUS Research Group. Corpas University, Bogotá, Colombia, Tel: +5716622222; Email: maria-mejia@juanncorpas.edu.co

\begin{abstract}
Background: Infections associated with health care (iahc) are all infections contracted by a patient during treatment in a hospital or other health center, and that said patient was not and was not incubating at the time of admission. In the world, 1 in 20 inpatients are affected, and in colombia the incidence is $5.9 \%$ of all hospitalized patients. HAI.

Objective: To describe the characteristics of HAI in pediatrics and to characterize the terms used during the care of pediatric patients with

Methods: Descriptive study divided into three phases; phase 1: a systematic search was performed on HAI in pediatrics in ebsco, pubmed and lilacs; phase 2: clinical cases of infections were designed, which were delivered to health professionals who had contact with the pediatric population, requesting that they make a brief analysis of the cases to make a theoretical model of predictive or present factors at the time of diagnosis, phase 3: the records of patients diagnosed with HAI during the period between 2014-2016 were reviewed and the demographic, social and clinical characteristics of these patients were identified. Frequencies were calculated, and the qualitative data were analyzed atlas ti 8.0.

Results: In the systematic search, predictive terms of common HAI were identified in the three databases as neonates, male sex, surgery among others, terms used by health professionals were obtained that coincided with those found in the scientific literature and finally were identified and analyzed the HAI cases of a third level clinic, finding an HAI rate of 0.46 per 100 hospital discharges.
\end{abstract}

Conclusion: There are terms that can be interpreted as predictive factors contributing to the early diagnosis of a HAI.

Keywords: Cross infection; Pediatrics; Forecasting

\section{Background}

The world health organization (who) defines as an infection associated with health care (HAI) "any infection contracted by a patient during his treatment in a hospital or other health center, and that said patient did not have nor was incubating at the time of your entry. " the HAI can affect patients in any type of environment in which they receive health care, they are the most frequent adverse event during the provision of health services, and no institution or country can claim to have solved the problem [1]. A study conducted by the who showed that more than 1.4 million people around the world suffer complications from infections acquired in the hospital; the most frequent infections being: those related to surgical wounds, urinary tract and lower respiratory tract, with higher prevalence in the surgical, orthopedic and intensive care unit (icu) services [2]. This phenomenon increases the morbidity and mortality of the users of the health system, increases the costs of the system, constitutes a biological risk for professionals, involves legal medical situations and also influences the quality aspects of the health service provider [3]. According to the who, an average of $8.7 \%$ of hospitalized patients have hais, of which 4384 are children [4]; the pan american health organization (paho) estimates that hais affect one in every 20 hospitalized patients, which corresponds to a total of 4.1 million patients per year, of which around 37,000 die [5]. In canada, some 220,000 hospital infections per year contract, resulting in 8,000 deaths related to this cause; in latin america, the prevalence of HAI is between $5 \%$ and $12 \%$ of hospitalized patients [6]. In chile, there are about 70000 cases of HAI and this has a cost of approximately usd 700,000 . In colombia, the incidence of HAI is $5.9 \%$ of the total 
number of hospitalized patients and in bogotá it is 2.4 per 1,000 hospital discharges. In the pediatric population, the incidence of mortality from hais is 1.7 deaths per 1000 live children [7,8].

In colombia, the national institute of health (ins) together with the national system of surveillance in public health (sivigila), responsible for providing information on events that affect the health of the colombian population in a systematic and timely manner [9], has two tools for the notification of cases the first corresponds to epidemiological prevention guidelines and control of HAI [10] and diagnostic criteria for infections associated with health care to be used for notification to the subsystem of epidemiological surveillance of iacs [11]; the second tool is a web application of the national subsystem for surveillance of infections associated with health care - HAI designed for the mandatory notification of infections associated with medical devices, antimicrobial resistance and antibiotic consumption by primary generating units of data (upgd); these tools facilitate the analysis of epidemiological indicators and the generation of reports $[12,13]$. Despite the implementation of the aforementioned tools, in the first quarter of 2017 there was a decrease in the reporting of HAI cases associated with the use of devices in $52.77 \%$ compared to the same period of 2016, a situation that can be be related to weaknesses in the surveillance processes of the upgd and the difficulties in the handling of the notification tool, this may correspond to the absence of an opportune diagnosis, since the mandatory notification to sivigila is made immediately after having a confirmed diagnosis of HAI, that is, after identifying an infectious process, in order to initiate antibiotic management; therefore, it is a late notification that does not lead to the prevention of the event and yes, to the increase of the bacterial resistance [14].

There are multiple options for an early diagnosis of HAI, which are divided into two groups; a clinical one, corresponding to signs and symptoms, which must be evaluated by medical personnel and a paraclinical one that includes laboratory tests [15]. In the last group, the blood culture stands out as the "gold standard" for the diagnosis of HAI and biomarkers such as simple pcr and pcr with modified dna, the latter generates an almost immediate report of the presence of an infection; procalcitonin, which has become a useful tool, both for diagnosis and for monitoring medical treatment; interleukin 6, definitive to define the treatment of HAI; endotracheal aspirate and catheter culture, among others [16-21].
Additionally, different diagnostic or predictive scales are available to evaluate infections in pediatrics, which relate clinical variables with laboratory parameters and apply to hais, among which are nosep i / ii and newborn scale of sepsis (sos), among the most used [22]; there are even systematized tools that emit alerts when detecting a possible $\mathrm{HAI}$, achieving an opportunity in the diagnosis and treatment of the infection, however this type of tools are barely in the early phase of implementation and there are still no clear results in the hospital community [23]; taking into account that colombia is a developing country, there are limitations to the use of certain paraclinical exams, mainly due to the cost that they generate for the health system; what conditions a diagnosis of HAI based on the clinical examination and laboratory tests, such as simple pcr, the blood count; and the blood culture that can take about 48 hours to identify definitive results that allow clinical behaviors to be taken. For this reason, the initial treatment is empirical and this contributes to the increase of the bacterial resistance (24). The objective of this research is to describe the demographic and social characteristics, as well as the clinical characteristics of the patients and the HAI in pediatrics and to characterize the terms used during the care of pediatric patients with HAI.

\section{Methods}

A descriptive study composed of three phases was carried out.

\section{First phase}

A systematic search was carried out in the databases ebsco, pubmed and lilacs, on articles that address the topic of medical terms related to HAI using the starlite strategy (Table 1) [25]. 626 articles were obtained in the period between June 2014 and June 2017 articles of which, after applying the selection criteria explained in table 1, 116 were selected to be analyzed and it was found that there are common terms in the three databases, that is, they are frequent in more than $75 \%$ of the selected articles, such as: neonates, male sex, prematurity, low weight, icu, prolonged hospital stay, cyanotic heart disease, venous catheter, nasogastric tube, corticosteroids, cannula orotracheal, mechanical ventilation, parenteral nutrition, pleural tube, bladder catheter, toys, immunosuppression, surgery, enteral nutrition, neutropenia, neoplasia, gastrointestinal disease, respiratory disease, tracheostomy, hiv (Table 2).

Table 1: Metodología STARLITE

\begin{tabular}{|c|c|}
\hline Sampling strategy & Selective \\
\hline Type of studies & Qualitative and quantitative studies \\
\hline Approaches & Book: Nelson, Treaty of Pediatrics, Internet search \\
\hline Range of years & Last 5 years, recent information \\
\hline Limits & Human, full texts, English and Spanish, age ( $<18$ years) \\
\hline Inclusion and exclusions & $\begin{array}{c}\text { Included: infections associated with health care, pediatrics Excluded: Incomplete, not recent, articles in animals, } \\
\text { other infections }\end{array}$ \\
\hline Terms used & $\begin{array}{l}\text { Nosocomial infections and Pediatrics Healthcare associated infections and pediatrics Hospital acquired infections } \\
\text { and children }\end{array}$ \\
\hline Electronic sources & PubMed, LILACS y EBSCO \\
\hline
\end{tabular}




\section{Academic Journal of Pediatrics \& Neonatology}

Table 2: Characteristics and findings of the systematic search.

\begin{tabular}{|c|c|c|c|}
\hline Measure & EBSCO & LILACS & PUBMED \\
\hline Terms & $\begin{array}{l}\text { Hospital acquired Infection, } \\
\text { health care associated infections, } \\
\text { nosocomial infections, pediatrics, } \\
\text { risk factor, predictors }\end{array}$ & $\begin{array}{l}\text { Cross infection, healthcare associated, } \\
\text { pediatric, risk factors }\end{array}$ & $\begin{array}{l}\text { healthcare associated infections, cross } \\
\text { infection, risk factors, child, preschool } \\
\text { infant, newborn }\end{array}$ \\
\hline STARLITE & See Table 1 & & \\
\hline Query & $\begin{array}{l}\text { (hospital acquired infections OR } \\
\text { health care associated infectons } \\
\text { OR nosocomial infections) AND } \\
\text { (pediatrics OR children) AND (risk } \\
\text { factors OR predictors) }\end{array}$ & $\begin{array}{l}\text { “CROSS INFECTION" or "HEALTHCARE- } \\
\text { ASSOCIATED" [Palabras] and } \\
\text { "PEDIATRIC" [Palabras] and “RISK } \\
\text { FACTORS" [Palabras] }\end{array}$ & $\begin{array}{c}\text { (Healthcare Associated Infections[mh] AND } \\
\text { ("Cross Infection/epidemiology”[Majr] OR } \\
\text { "Cross Infection/statistics and numerical } \\
\text { data"[Majr] ) AND “Risk Factors"[tiab]) } \\
\text { AND ( ( ( child, preschool[MeSH] OR infant, } \\
\text { newborn[MeSH] OR infant[MeSH] OR } \\
\text { infant[MeSH:noexp] OR child[MeSH:noexp] } \\
\text { ) ) }\end{array}$ \\
\hline Limits & $\begin{array}{l}\text { Date of publication: last } 5 \text { years, } \\
\text { Age: birth - } 18 \text { years, human, full } \\
\text { texts, English and Spanish. }\end{array}$ & & \\
\hline Number of articles & 34 & 22 & 115 \\
\hline Risk factors & $\begin{array}{c}\text { Newborns [26,29], male } \\
{[27,29,35,36,40,45], \text { prematurez }} \\
{[27,29,34,41,42,47], \text { low weight }} \\
{[27,29,34,41,44], \text { UCI }[26,30,} \\
34,42,46], \text { length hospital stancy } \\
{[32,33,38,40,46], \text { cardiopaty }} \\
{[28,38], \text { catheter }(27,31-36,38),} \\
\text { nasogastric tube }[28,31,38,46], \\
\text { corticosteroids }[34,35], \\
\text { orotracheal cannula }[28,38], \\
\text { mechanical ventilation }[28,29,31- \\
34,36,44,46,47], \text { malnutrition } \\
(28,34,38,40), \text { parenteral } \\
\text { nutrition }(31,34,41,42,44), \\
\text { pleural tube }[28,38], \text { bladder } \\
\text { catheter }[31,33,34], \text { toys }[30], \\
\text { immunosuppression }[30,36,30], \\
\text { surgery }[31,33,34,30,42,44,45,47], \\
\text { enteral nutrition }[32,34,36], \\
\text { neutropenia }[32,34], \text { neoplasia } \\
{[33,34], \text { gastrointestinal disease }} \\
{[34,44], \text { respiratory disease, }} \\
\text { tracheostomy }[33,40,43], \text { HIV } \\
{[34,47] .}\end{array}$ & $\begin{array}{c}\text { Mechanical ventilation [48,57-58], } \\
\text { prolonged hospital stay [50, 55, 58, 60- } \\
62,64] \text {, prematurity [64], previous use } \\
\text { of antimicrobials }(48-52,55,56,58,61- \\
\text { 62), parenteral nutrition }(57-58,62), \\
\text { nasogastric tube }(48,54-55), \text { ICU } \\
\text { (51,59, 61), immunosuppression } \\
\text { [48,41,56,58,59], neutropenia [50], } \\
\text { venous catheter [55, 59, 61], co } \\
\text { morbidities [48,52,55,56,61], surgery } \\
\text { [43,57,60], neoplasms [49], low weight } \\
\text { [53], neonates [53], tracheostomy [54], } \\
\text { bladder catheter [58], malnutrition } \\
\text { [58-60], incomplete or absent } \\
\text { breastfeeding, recent hospital discharge, } \\
\text { low socioeconomic status, poor grade of } \\
\text { family members, poor quality of medical } \\
\text { care and poor access to health services } \\
\text { [58], cyanogenic heart disease [59] }\end{array}$ & 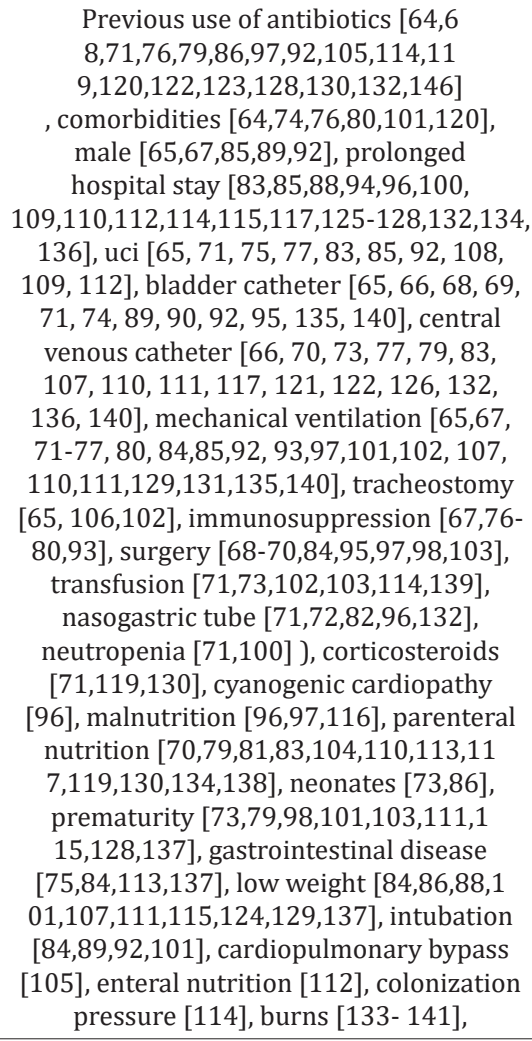 \\
\hline
\end{tabular}

\section{Second phase}

Subsequently, in order to identify the terms used by health personnel (paediatricians, neonatologists, general practitioners, residents, nurses) within the clinical histories during the phase of suspicion or diagnosis of a patient with HAI, they were designed four clinical cases, one contained signs and symptoms suggestive of the start of an infection, another contained paraclinicos confirmatory of infection, another was an HAI and a last was the negative control which did not suggest infection (see supplementary material 1 ). The clinical cases were included in a questionnaire that requested to write to the health professional an evolution of the clinical case. The questionnaire was applied in three health institutions of the city of bogotá and additionally, it inquired about the health area in which the professional practiced, the time of experience and the place where he worked. The data were analyzed with the atlas ti program, .8.1 taking into account that they were qualitative data (Table $3 \& 4$ ). 


\section{Academic Journal of Pediatrics \& Neonatology}

Table 3: General data of the survey applied to health professionals.

\begin{tabular}{|c|c|c|}
\hline Measure & $\mathbf{n}$ & $\%$ \\
\hline \multicolumn{3}{|l|}{ Health Area } \\
\hline Audit or Administration in Health & 6 & 25 \\
\hline Bacteriology & 2 & 8.3 \\
\hline Nursery & 5 & 20.83 \\
\hline General Medicine & 5 & 20.83 \\
\hline Pedíatrícs & 3 & 12.5 \\
\hline Neonatology & 2 & 8.03 \\
\hline Radiology & 1 & 4.16 \\
\hline \multicolumn{3}{|l|}{ Experience Time } \\
\hline 1 a 3 years & 13 & 54.16 \\
\hline 3 a 5 years & 3 & 12.5 \\
\hline$>5$ years & 8 & 23.3 \\
\hline \multicolumn{3}{|l|}{ Lugar de Trabajo } \\
\hline $\mathrm{CJNC}$ & 10 & 41.6 \\
\hline Hospital de Kennedy & 7 & 29.16 \\
\hline Hospital San Ignacio & 4 & 16.66 \\
\hline Hospital Santa Clara & 1 & 4.16 \\
\hline Clínica La Colina & 1 & 4.16 \\
\hline Hospital Militar Central & 1 & 4.16 \\
\hline
\end{tabular}

CJNC: Clínica Juan N. Corpas

Table 4: Qualitative findings of the survey applied to professionals in the health area.

\begin{tabular}{|c|c|c|c|c|}
\hline Term & Frequency & & & \\
\hline & Case 1 & Case 2 & Case 3 & Case 4 \\
\hline \multicolumn{5}{|l|}{ Terms related to clinical findings } \\
\hline Rales & 10 & - & - & - \\
\hline Leukocytosis & 12 & - & - & - \\
\hline Neutrophilia & 10 & - & - & - \\
\hline Saturation & 10 & - & - & - \\
\hline Proper evolution & - & 17 & - & - \\
\hline Phlebitis & - & - & 9 & - \\
\hline \multicolumn{5}{|l|}{ Terms related to medications } \\
\hline Antibiotic & 11 & - & 11 & 11 \\
\hline Antipyretic & 12 & - & 12 & - \\
\hline Endovenous & 11 & - & 8 & - \\
\hline Spread spectrum & 8 & - & - & - \\
\hline Liquids & 8 & - & - & - \\
\hline Oxygen & 7 & - & - & - \\
\hline \multicolumn{5}{|l|}{ Terms related to HAI } \\
\hline Complication & 12 & - & 12 & - \\
\hline Length hospital stay & 25 & - & 8 & 12 \\
\hline Respiratory infection & 9 & - & - & - \\
\hline Pneumonia & 16 & - & - & - \\
\hline Nosocomial & 10 & - & 10 & 10 \\
\hline Catheter-associated infection & - & - & 18 & - \\
\hline Cellulitis & - & - & 15 & - \\
\hline
\end{tabular}




\section{Academic Journal of Pediatrics \& Neonatology}

\begin{tabular}{|c|c|c|c|c|}
\hline Neurological infection & - & - & - & 12 \\
\hline Meningitis & - & - & - & 10 \\
\hline \multicolumn{5}{|c|}{ Terms related to the conduct to be followed } \\
\hline Request paraclinics & 16 & - & 14 & 25 \\
\hline Monitor vital signs & 22 & - & - & 17 \\
\hline Departure & - & 6 & - & - \\
\hline Request blood cultures & - & - & 12 & - \\
\hline Start antibiotic management & - & - & 11 & - \\
\hline Continue antibiotic management & - & - & - & 17 \\
\hline Isolation by contact & - & - & - & 9 \\
\hline
\end{tabular}

Case 1: signs and symptoms suggestive of the onset of an infection, Case 2: negative control, Case 3: Confirmatory paraclinics of infection, Case 4: HAl confirmed.

Third phase: once the terms used in the scientific literature and in the clinical cases analyzed by health professionals in contact with the pediatric population were identified, the records of patients diagnosed with HAI in a third-level clinic during the study period were reviewed. Time between august 2014 and august 2016, the records were obtained through two sources, the first was the database obtained from the department of epidemiology of the institution and the second, from the search for cie diagnoses 10 related to HAI in the general database of the institution, the two databases were compared and a total of 96 cases of HAI were obtained, of which 12 corresponded to pediatric patients; 6 neonates and six older than 30 days of age; we found an average age of 12.3 days in neonates and 12 years in the other patients, an incidence of 75 infections per 1000 days of hospital stay was calculated. Of the total number of patients, $75 \%$ were male, all lived in urban areas; $91.6 \%$ of the population belonged to a middle stratum, however all were of the subsidized health regime. Regarding the family environment, we found that $83 \%$ of patients were cared for by their mothers who had an average age of 37 years, in terms of the academic training of caregivers $83 \%$ were high school graduates and $17 \%$ had technical studies.

In the evaluation of clinical variables of the patients, it was identified that the most frequent type of feeding during the days of hospital stay was enteral, followed by breastfeeding; the most frequent HAI was the bloodstream infection associated with the use of catheter, the most used diagnostic method was the culture of catheter tip followed by physical examination, the most frequently isolated microorganism was staphylococcus epidermidis as a producer of HAI, half of the cases of HAI was presented in the nicu and the remaining half in other hospitalization services; the most used medical devices were the venoclysis equipment that was used in all patients, followed by the central catheter in four patients, and nasal cannulas in $33.3 \%$ of the population studied; $75 \%$ of the cases had some type of isolation, with contact being the most frequent (Table 5). Finally, based on the information found in the three sources: scientific literature, surveys of health professionals and review of medical records, a triangulation of the information was carried out and, in addition to identifying the most frequently used terms, it proposes a list of terms and characteristics that could alert the triggering or the presence of an HAI in real time which includes characteristics of the patient such as male sex or age less than 30 days of life; clinical characteristics such as the use of any invasive medical device, especially the use of venous catheter, surgical intervention, hospitalization in the icu, enteral nutrition and prolonged hospital stay, that is, more than 7 days in any hospitalization service (Table 6).

Table 5: Characteristics of HAI found in a third level clinic in Bogotá.

\begin{tabular}{|c|c|}
\hline Measure & n (\%) \\
\hline \multicolumn{2}{|l|}{ HAI } \\
\hline Bacteremia & $8(66,6 \%)$ \\
\hline OSI & $2(16,6 \%)$ \\
\hline Pneumonia & $1(8,4 \%)$ \\
\hline Endometritis & $1(8,4 \%)$ \\
\hline \multicolumn{2}{|l|}{ Diagnostic Method } \\
\hline Catheter tip culture & $6(50 \%)$ \\
\hline Physical exam & $3(25 \%)$ \\
\hline Blood culture & $2(16,6 \%)$ \\
\hline Transvaginal ultrasound & $1(8,4 \%)$ \\
\hline \multicolumn{2}{|l|}{ Isolated microorganism } \\
\hline S. epidermidis & $8(66,6 \%)$ \\
\hline S. viridians & $1(8,4 \%)$ \\
\hline S. aureus & $2(16,6 \%)$ \\
\hline H. influenzae & $1(8,4 \%)$ \\
\hline \multicolumn{2}{|l|}{ Identification Service } \\
\hline Emergency & $1(8,4 \%)$ \\
\hline $\mathrm{NICU}$ & $6(50 \%)$ \\
\hline Pediatrics & $5(41,6 \%)$ \\
\hline \multicolumn{2}{|l|}{ Isolated } \\
\hline Yes & $9(75 \%)$ \\
\hline Contact & $8(88,8 \%)$ \\
\hline Air & $1(12,1 \%)$ \\
\hline No & $3(25 \%)$ \\
\hline \multicolumn{2}{|l|}{ Treatment } \\
\hline Clindamicin & $1(8,4 \%)$ \\
\hline Ampicillin/Gentamicin & $8(66,6 \%)$ \\
\hline Piperacillin/Tazobactam & $1(8,4 \%)$ \\
\hline
\end{tabular}




\begin{tabular}{|c|c|}
\hline Oxacillin & $2(16,6 \%)$ \\
\hline Change of treatment & \\
\hline Yes & $6(50 \%)$ \\
\hline Vancomicin/Meropenem & $6(100 \%)$ \\
\hline No & $6(50 \%)$ \\
\hline
\end{tabular}

OSI: Operative Site Infection, NICU: Neonatal Intensive Care Unit.

Table 6: List of terms and characteristics to suspect HAI.

\begin{tabular}{|c|c|c|}
\hline Measure & Yes & No \\
\hline Male & & \\
\hline Newborn & & \\
\hline Use of medical device & & \\
\hline Surery & & \\
\hline NICU & & \\
\hline Enteral nutrition & & \\
\hline Length hospital stay & & \\
\hline
\end{tabular}

\section{Discussion}

This investigation allowed to identify the characteristics and terms related to HAI, aspects that could be considered as warning signs during the first approach in pediatric patient care; determined the HAI events in pediatrics in a third level clinic and identified the social, demographic and clinical characteristics of the population studied. The innovative aspect of this study is that it provides information from three sources of data: the scientific literature, the clinical practice of health professionals and the records in medical records; in which the terms used were found to coincide; the foregoing assumes that the theory is not far from the practice and that the identified terms can be considered to make an early and accurate diagnosis of an HAI or to alert about the probability of suffering it during medical attention [24, 26-31, 67- 89]. It has been described that the first to identify this type of infection are the nurses or the epidemiological surveillance departments of the health entities, but with the terms found in this research, this role of early identification of HAI can be attributed to any professional of the health in contact with the patient $[12,23-$ 24].

The place of selection of participants, allowed to identify individuals of different socioeconomic level, the majority belonging to medium and low stratum, aspect that has evidenced relation with the presentation of HAI in other studies carried out [24]. Contrary to some studies that identify the rural area as a risk factor for contracting an infection, in this study none of the cases lived in a non-urban area [142-143]. It was found that the majority of patients who acquired an hai were male, a finding consistent with multiple studies, which estimated that for every two male patients, one was female [144-148]. As well as studies conducted in north america and europe, the most frequent HAI was related to bloodstream infection associated with catheter use, and the most isolated microorganism was the staphylococcus epidermis present in the catheter tip culture; this finding is consistent with what was found in this research [149-153]. The literature describes multiple risk factors for contracting an HAI and some authors indicate that the combination of several of these factors may increase the risk of acquiring an HAI; it is also known that hais prolong the hospital stay of hospitalized pediatric patients, increase their morbidity and mortality and cause greater economic and human expenses that affect the health system [154-160]. The authors considered as a limitation the low number of cases found during the study period.

Finally, based on the results obtained, a list of characteristics that can alert the health professional about the presence of an HAI in the first contact with the patient is proposed, for this purpose, in a future investigation it is intended to generate a probability score of risk that will allow classifying patients in those with low, medium and high risk of HAI, at different times of hospitalization, including: admission, 24-48 hours, 49-72 hours and 73-96 hours. It would be of great value, due to the importance of reducing the HAI in the institutions, giving greater weight to the prevention of them with this information.

\section{Conclusion}

Most of the patients are male, they are cared for by one of the parents only, they belong to the middle stratum and they are subsidized. The most frequent HAI was the infection associated with the use of venous catheter. There are common characteristics and terms related to HAI that can alert on the appearance or course of an infection of this type. It is important to focus on the prevention of hais from the first contact with the patient through the use of basic tools such as epidemiological characteristics and clinical history.

\section{Acknowledgement}

To Juan N Corpas University.

\section{References}

1. OMS (2013) Carga mundial de infecciones asociadas a la atención sanitaria.

2. OMS (2018) 10 datos sobre seguridad del paciente.

3. OMS (2005) Reto mundial en pro de la seguridad del paciente 20052006.

4. Ministerio de Salud (2013) Infecciones asociadas a la Atención en Salud (HAI) y Resistencia antimicrobiana. Programa Nacional de Promoción, Prevención Vigilancia y Control.

5. Cabrera J, Holder R, Pardo P, Stempiluk V (2013) Vigilacia Epidemiológica de las Infecciones Asociadas a la Atención de la Salud. Organización Panamerican de la Salud.

6. Instituto Nacional de Salud (2015) Protocolo de Vigilancia en Salud Pública. Infecciones Asociadas a Dispositivos INS 1: 26-45.

7. Ministerio de Salud de la Nación de Argentina. Programa Nacional de Epidemiología y Control de Infecciones Hospitalarias (VIHDA).

8. Ministerio de Salud de Chile. Infecciones Intrahospitalarias y asociadas a la atención en Salud.

9. Ministerio de Salud Pública de Uruguay. Control de infecciones intrahospitalarias.

10. Rosenthal VD, Maki DG, Salomao R, Moreno CA, Mehta Y, et al. Deviceassociated nosocomial infections in 55 intensive care units of 8 developing countries. Ann Intern Med 145(8): 582-591. 
11. Schmunis GA (2008) Costo de la infección nosocomial en unidades de cuidados intensivos de cinco países de América Latina: llamada de atención para el personal de salud. Rev Panam Infectol 10(4 Supl 1): S70-S77.

12. Ministerio de Salud y Protección Social. Circular 045: Implementación de la estrategia de vigilancia en salud pública de infecciones asociadas a la atención en salud- HAI , Resistencia y consumo de antmiccrobianos 2012 .

13. Ministerio de Salud y Protección Social. Circular 045 del 2012: Implementación de las estrategias e vigilancia de Infecciones Asociadas a la Atención en Salud, Resistencia y Consumo de Antibióticos. Disponible en:

14. Instituto Nacional de Salud (2018) Informe del evento de infecciones asociadas a dispositivos, Fecha de consulta: Febrero de.

15. Maldonado N, Villamil MAL, Velásquez VL, Robledo J, Restrepo CGR (2013) Caracterización de los programas de prevención y control de infecciones en instituciones hospitalarias de Medellín -Colombia, 2011. En Infect 17(3): 136-145.

16. Política de prevención, control y vigilancia epidemiológica de infecciones intrahospitalaria (IIH) para Bogotá, D.C. Secretaría Distrital de Salud de Bogotá DC - Dirección de Salud Pública.

17. Observatorio de la calidad de Atención en Salud.

18. Secretaría Distrital de Salud. Boletín epidemiológico distrital de infecciones intrahospitalarias año 2007. Publicación Secretaría Distrital de Salud. [En línea] Bogotá 2009. [Fecha de acceso noviembre 05 de 2009]. URL: disponible en:

19. Instituto Nacional de Salud http://www.ins.gov.co/Paginas/inicio. aspx

20. Ministerio de Salud y Protección Social. Circular 045: Implementación de la estrategia de vigilancia en salud pública de infecciones asociadas a la atención en salud- HAI , Resistencia y consumo de antmiccrobianos.2012.

21. Secretaria Distrital de Salud. Criterios Diagnósticos de Infecciones Asociadas al Cuidado de la Salud a ser utilizados para la notificación al subsistema de vigilancia epidemiológica de IACS en Bogotá D.C. 2010. Disponible en: http://www.saludcapital.gov.co/sitios/ VigilanciaSaludPublica/SiteCollectionDocuments/Criterios $\% 20$ diagnosticos\%20IACS\%20para\%20Bogot\%C3\%A1.pdf (Último acceso Febrero 12/2016).

22. Instituto Nacional de Salud. Manual de Usuarios del Aplicativo HAI. 2012

23. Yoon HS.Neonatal innate immunity and Toll-like receptor. Department of Pediatrics.Seoul. Korea: EuljiHospital. 2010

24. Ali R, Ahmed S, Qadir M, Maheshwari P, Khan R.Pneumothoraces in a neonatal tertiary care unit: case series. Karachi: Department of Pediatrics and Child Health. Aga Khan University Hospital.2013

25. Booth A. "Brimful of STARLITE": toward standards for reporting literature searches. J Med Libr Assoc. 2006 Oct;94(4):421-9, e205.

26. Santisteban Y, Carmona Y, Pérez Y, Díaz L, García S, et al. (2014) Infecciones por los géneros Klebsiella y Acinetobacter en hospitales pediátricos cubanos y resistencia antibiótica. Revista Cubana de Medicina Tropical 66(3): 400-414.

27. García H, Martínez A, Peregrino L (2014) Epidemiología de las infecciones nosocomiales en una unidad de cuidados intensivos neonatales. Rev Med Inst Mex Seguro Soc 52 Supl 2: S30-S37.

28. Duarte F, Baeza F (2016) Incidencia y factores de riesgo asociados a infección nosocomial en cardiocirugía pediátrica. Rev Med Inst Mex Seguro Soc 54(2): 182-189.

29. López C, Macías H (2013) Neumonía asociada a ventilación en neonatos: Factores de riesgo. Revista de Enfermedades Infecciosas en Pediatría XXVII: 105.

30. Barragán A, López P (2012) Factores de riesgo para infecciones nosocomiales en Pediatría. Revista Gastrohnup 14(2): S1: S7-S13.
31. Barragán A, López P (2012) Factores de riesgo para infecciones nosocomiales en Pediatría. Revista Gastrohnup 14(2): S1: S7-S13.

32. Aktar F, Tekin R, GüneG A, Ülgen C, Tan E, et al. (2016) Determining the Independent Risk Factors and Mortality Rate of Nosocomial Infections in Pediatric Patients. Hindawi Publishing Corporation BioMed Research International Volume 2016, Article ID 7240864, p. 5.

33. Lombardo E, Hernández H, Perez V, Orozco H, Soto E, et al. (2012) Estudio de prevalencia puntual en un hospital pediátrico de tercer nivel. Acta Pediatr Mex 33(2): 76-79.

34. Akeme Yamamoto AC, de Paula CR, Dias LB, Tadano T, Martins ÉR, et al. (2012) Epidemiological and clinical characteristics of nosocomial candidiasis in university hospitals in Cuiabá - Mato Grosso, Brazil. Rev Iberoam Micol 29(3): 164-168.

35. Roy A, Corvos M, Franco A, Stranieri F, Figueroa M, Silva Z, et al. (2012) Infecciones Intrahospitalarias en Pacientes con Leucemia Aguda del Servicio de Hematología, Ciudad Hospitalaria Dr. Enrique Tejera. Informe médico 14(5): 223-229.

36. Cooper VB, Haut C (2013) Preventing Ventilator Associated Pneumonia in Children: An Evidence Based Protocol. Crit Care Nurse 33(3): 21-29.

37. Oladokun R, Muloiwa R, Hsiao N, Valley Z, Nuttall J, et al. (2016) Clinical characterisation and phylogeny of respiratory syncytial virus infection in hospitalised children at Red Cross War Memorial Children's Hospital, Cape Town. BMC Infectious Diseases 16: 236.

38. Duarte F, Baeza F (2016) Incidencia y factores de riesgo asociados a infección nosocomial en cardiocirugía pediátrica. Rev Med Inst Mex Seguro Soc 54(2): 182-189.

39. Awasthia S, Tahazzula M, Ambasta A, Govila Y, Jainb A (2013) Longer duration of mechanical ventilation was found to be associated with ventilator-associated pneumonia in children aged 1 month to 12 years in India. J Clin Epidemiol 66(1): 62-66.

40. Naidoo R, Nuttall J, Whitelaw A, Eley B (2013) Epidemiology of Staphylococcus aureus Bacteraemia at a Tertiary Children's Hospital in Cape Town, South Africa. Plos one 8(10): e78396.

41. Yumani D, van den Dungen F, van Weissenbruch M (2013) Incidence and risk factors for catheter-associated bloodstream infections in neonatal intensive care. Foundation Acta Pædiatr 102(7): e293-e298.

42. Yuan Y, Zhou W, Rong X, Lu WN, Zhang Z (2015) Incidence and factors associated with nosocomial infections in a neonatal intensive care unit (NICU) of an urban children's hospital in China. Clin Exp Obstet Gynecol 42(5): 619-628.

43. Phongjitsiri S, Coss-Bu J, Kennedy C, Silva J, Starke J, et al. (2015) The Centers for Disease Control and Prevention's New Definitions for Complications of Mechanical Ventilation Shift the Focus of Quality Surveillance and Predict Clinical Outcomes in a PICU. Crit Care Med 43(11): 2446-2451.

44. Verstraete EH, De Coen K, Vogelaers D, Blot S (2015) Risk Factors for Health Care-Associated Sepsis in Critically Ill Neonates Stratified by Birth Weight. Pediatr Infect Dis J 34(11): 1180-1186.

45. Koch AM, Nilsen RM, Dalheim A, Cox RJ, Harthug S (2015) Need for more targeted.Need for more targeted measures - only less severe hospital-associated infections declined after introduction of an infection control program. J Infect Public Health 8(3): 282-290.

46. Kusahara DM, Enz Cda C, Avelar AF, Peterlini MA, Pedreira Mda L (2014) Risk factors for ventilator-associated pneumonia in infants and children: a cross-sectional cohort study. Am J Crit Care 23(6): 469-476.

47. Gadallah MA, Aboul Fotouh AM, Habil IS, Imam SS, Wassef G (2014) Surveillance of health care-associated infections in a tertiary hospital neonatal intensive care unit in Egypt: 1-year follow-up. Am J Infect Control 42(11): 1207-1211.

48. Maccioni A, Abarca K, Terrazas C, Cerda J (2015) Clinic and epidemiologic description of Clostridium difficile infection in a pediatric population. Rev chil Infectol 32(5): 523-529. 
49. Costa P, Atta e, Hallack S, Silva A (2015) Infection with multidrugresistant gram-negative bacteria in a pediatric oncology intensive care unit: risk factors and outcomes. J pediatr (Rio J) 91(5): 435-441.

50. Loyola P, Acuña M, Yohannessen K, Benadof D, Tordecilla J (2015) Risk factor of intestinal colonization with vancomycin resistant Enterococcus spp in hospitalized pediatric patients with oncological disease. Rev chil Infectol 32(4): 393-398.

51. Kara A, Gülfidan G, Apab H, Demiray N, Oruç Y, Kıran E, et al. (2015) Risk of vancomycin-resistant enterococci bloodstream infection among patients colonized with vancomycin-resistant enterococci. Braz J infect Dis 19(1): 58-61.

52. Costa Pde O, Atta EH, Silva AR (2014) Predictors of 7- and 30-day mortality in pediatric intensive care unit patients with cancer and hematologic malignancy infected with Gram-negative bacteria. Braz. J infect Dis 18(6): 591-599.

53. Barriga J, Ferrés M, Abarca K, Cerda J, Fajuri P, et al. (2014) Nosocomial infections after cardiac surgery in infants and children with congenital heart disease. Rev chil Infectol 31(1):16-20.

54. Flores B, Chateau I, Flores O, Montes F, Espinoza P, et al. (2013) Adenovirus infection in a children's hospital with chronic pulmonary diseases. Rev chil Pediatr 84(5): 522-526.

55. Faruk E, BayramII N, DevrimII I, ApaI H, GülfidanI G, (2013) Estimating risk factors for acinetobacter bacteremia in pediatric settings. Braz J infect Dis 17(4): 505-506.

56. Valverde Y (2011) Epidemiological, pathophysiological and clinical fundamentals of sepsis in children: [review]. Medisan 15(8).

57. Londono F, Ardila A, Ossa M (2011) Epidemiología de la infección asociada a catéter venoso central/ Epidemiology of infections of central venous catheters. Rev chil Pediatr 82(6): 493-501.

58. Mello MJ, Albuquerque Mde F, Lacerda HR, Souza WV, Correia JB, et al. (2009) Risk factors for healthcare-associated infection in pediatric intensive care units: a systematic review. Cad saúde pública 25(supl.3): S373-S391.

59. Lopes J, Goulart E, Andrade M, Starling C, Ferreira E (2007) Pediatric mortality due to nosocomial infection: a critical approach. Braz J infect Dis 11(5): 515-519.

60. Bravo L, Lambert J, Oliva M, Miranda Pérez Y, Machado O, et al. (2006) Factores de riesgo de infección nosocomial después de cirugía cardíaca pediátrica. Rev cuba Pediatr 78(3).

61. Arnoni MV, Berezin EN, Martino MD (2007) Risk factors for nosocomial bloodstream infection caused by multidrug resistant gram-negative bacilli in pediatrics. Braz J Infect Dis 11(2): 267-271.

62. Bicudo EL, Macedo VO, Carrara MA, Castro FF, Rage RI (2007) Nosocomial outbreak of Pantoea agglomerans in a pediatric urgent care center. Braz J Infect Dis 11(2): 281-284.

63. Chang MR, Carvalho NCP, Oliveira ALL, Moncada PMF, Moraes BA, et al. (2003) Surveillance of pediatric infections in a teaching hospital in Mato Grosso do Sul, Brazil. Braz J Infect Dis 7(2): 149-160.

64. Wang J, Wang Y, Du X, Cui J, Wang K, et al. (2016) Rapid transmission of multidrug-resistant Corynebacterium striatum among susceptible patients in a tertiary hospital in China. J Infect Dev Ctries 10(12): 1299-1305.

65. Chen Y, Zhao JY, Shan X, Han XL, Tian SG, et al. (2017) A pointprevalence survey of healthcare-associated infection in fifty-two Chinese hospitals. J Hosp Infect 95(1): 105-111.

66. El-Feky EA, Saleh DA, El-Kholy J, Sayed AM, Mansi Y, et al. (2017) Use of personal digital assistants to detect healthcare-associated infections in a neonatal intensive care unit in Egypt. J Infect Dev Ctries 10(11):1250-1257.

67. Vergeire-Dalmacion GR, Itable JR, Baja ES (2016) Hospital-acquired infection in public hospital buildings in the Philippines: Is the type of ventilation increasing the risk?. J Infect Dev Ctries 10(11): 12361242 .
68. Abu Faddan NH, Aly SA, Abou Faddan HH (2016) Nosocomial Clostridium difficile-associated diarrhoea in Assiut University Children's Hospital, Egypt. Paediatr Int Child Health 36(1): 39-44.

69. Dramowski A, Whitelaw A, Cotton MF (2016) Burden, spectrum, and impact of healthcare-associated infection at a South African children's hospital. J Hosp Infect 94(4): 364-372.

70. Le NK, Hf W, Vu PD, Khu DT, Le HT, et al. (2016) High prevalence of hospital-acquired infections caused by gram-negative carbapenem resistant strains in Vietnamese pediatric ICUs: A multi-centre point prevalence survey. Medicine (Baltimore) 95(27): e4099.

71. Aktar F, Tekin R, Güneş A, Ülgen C, Tan İ, et al. (2016) Determining the Independent Risk Factors and Mortality Rate of Nosocomial Infections in Pediatric Patients. Biomed Res Int 2016: 7240864.

72. Duarte-Raya F, Baeza-Zarco FJ (2016) Incidence and risk factors associated with nosocomial infection in pediatric heart surgery. Rev Med Inst Mex Seguro Soc 54(2): 182-189.

73. Ndir A, Diop A, Faye PM, Cissé MF, Ndoye B, et al. (2016) Epidemiology and Burden of Bloodstream Infections Caused by Extended-Spectrum Beta-Lactamase Producing Enterobacteriaceae in a Pediatric Hospital in Senegal. PLoS ONE 11(2): e0143729.

74. Kabbani MS, Ismail SR, Fatima A, Shafi R, Idris JA, et al. (2016) Urinary tract infection in children after cardiac surgery: Incidence, causes, risk factors and outcomes in a single-center study. J Infect Public Health. 9(5):600-610.

75. Tripathi A, Shukla SK, Singh A, Prasad KN (2016) Prevalence, outcome and risk factor associated with vancomycin-resistant Enterococcus faecalis and Enterococcus faecium at a Tertiary Care Hospital in Northern India. Indian J Med Microbiol 34(1): 38-45.

76. Maccioni A, Cerda J, Terrazas C, Abarca K (2015) Clinic and epidemiologic description of Clostridium difficile infection in a pediatric population. Rev Chilena Infectol 32(5): 523-529.

77. García H, Torres-Gutiérrez J, Peregrino-Bejarano L, Cruz-Castañeda MA Risk factors for nosocomial infection in a level III Neonatal Intensive Care Unit. Gac Med Mex 151(6): 711-179.

78. Kurdyumova NV, Danilov GV, Ershova ON, Savin IA, Sokolova EY, et al. (2015) Features of the course of nosocomial meningitis in patients of neurosurgical intensive care unit. Zh Vopr Neirokhir Im N N Burdenko 79(3): 55-59.

79. Yuan Y, Zhou W, Rong X, Lu WN, Zhang Z (2015) Incidence and factors associated with nosocomial infections in a neonatal intensive care unit (NICU) of an urban children's hospital in China. Clin Exp Obstet Gynecol 42(5): 619-628.

80. Phongjitsiri S, Coss-Bu J, Kennedy C, Silva J, Starke J, et al. (2015) The Centers for Disease Control and Prevention's New Definitions for Complications of Mechanical Ventilation Shift the Focus of Quality Surveillance and Predict Clinical Outcomes in a PICU. Crit Care Med 43(11): 2446-2451.

81. Wang D, Lai X, Liu C, Xiong Y, Zhang X Influence of supplemental parenteral nutrition approach on nosocomial infection in pediatric intensive care unit of Emergency Department: a retrospective study Nutr J 14: 103.

82. Goel K, Randhawa VS, Saili A, Khare S, Kumar A, et al. (2016) Incidence, Etiology and Risk Factors Associated with Neonatal HealthcareAssociated Conjunctivitis: A Prospective Study from a Tertiary Care Hospital in India. J Trop Pediatr. 2016 Feb;62(1):10-8.

83. Schröder C, Schwab F, Behnke M, Breier AC, Maechler F, et al. (2015) Epidemiology of healthcare associated infections in Germany: Nearly 20 years of surveillance. Int J Med Microbiol 305(7): 799-806.

84. Verstraete EH, De Coen K, Vogelaers D, Blot S (2015) Risk Factors for Health Care-Associated Sepsis in Critically Ill Neonates Stratified by Birth Weight. Pediatr Infect Dis J 34(11): 1180-1186.

85. Ortega HW, Cutler G, Dreyfus J, Flood A, Kharbanda A (2015) Hospitalacquired pneumonia among pediatric trauma patients treated at national trauma centers. J Trauma Acute Care Surg 78(6): 1149-1154. 
86. Nikkhoo B, Lahurpur F, Delpisheh A, Rasouli MA, Afkhamzadeh A (2015) Neonatal blood stream infections in tertiary referral hospitals in Kurdistan, Iran. Ital J Pediatr 41: 43.

87. Milczewska J, Wołkowicz T, Zacharczuk K, Kwiatkowska M (2015) Cross-infections with Pseudomonas aeruginosa in patients with cystic fibrosis attending the Warsaw Centre. Dev Period Med 19(1): 60-65

88. Różańska A, Wójkowska-Mach J, Adamski P, Borszewska-Kornacka M, Gulczyńska E, et al. (2015) Infections and risk-adjusted length of stay and hospital mortality in Polish Neonatology Intensive Care Units. Int J Infect Dis 35: 87-92.

89. Deptuła A, Trejnowska E, Ozorowski T, Hryniewicz W (2015) Risk factors for healthcare-associated infection in light of two years of experience with the ECDC point prevalence survey of healthcareassociated infection and antimicrobial use in Poland. J Hosp Infect $90(4): 310-315$

90. Lee NG, Marchalik D, Lipsky A, Rushton HG, Pohl HG, et al. (2016) Risk Factors for Catheter Associated Urinary Tract Infections in a Pediatric Institution. J Urol 195(4 Pt 2): 1306-1311.

91. Ammann RA, Laws HJ, Schrey D, Ehlert K, Moser O, et al. (2015) Bloodstream infection in paediatric cancer centres--leukaemia and relapsed malignancies are independent risk factors. Eur J Pediatr 174(5): 675-686.

92. Kepenekli E, Soysal A, Yalindag-Ozturk N, Ozgur O, Ozcan I, et al. (2015) Healthcare-Associated Infections in Pediatric Intensive Care Units in Turkey: a National Point-Prevalence Survey. Jpn J Infect Dis 68(5): 381-386

93. Gupta S, Boville BM, Blanton R, Lukasiewicz G, Wincek J, et al. ( 2015) Forbes ML.A multicentered prospective analysis of diagnosis, risk factors, and outcomes associated with pediatric ventilator-associated pneumonia. Pediatr Crit Care Med 16(3): e65-e73.

94. Resende DS, Peppe AL, dos Reis H, Abdallah VO, Ribas RM, et al. (2015) Late onset sepsis in newborn babies: epidemiology and effect of a bundle to prevent central line associated bloodstream infections in the neonatal intensive care unit. Braz J Infect Dis 19(1): 52-57.

95. Koch AM, Nilsen RM, Dalheim A, Cox RJ, Harthug S (2015) Need for more targeted measures - only less severe hospital-associated infections declined after introduction of an infection control program. J Infect Public Health 8(3): 282-90

96. Kusahara DM, Enz Cda C, Avelar AF, Peterlini MA, Pedreira Mda L (2014) Risk factors for ventilator-associated pneumonia in infants and children: a cross-sectional cohort study. Am J Crit Care 23(6): 469-476.

97. Gupta A, Patel R, Baddour LM, Pardi DS, Khanna S (2014) Extraintestinal Clostridium difficile infections: a single-center experience. Mayo Clin Proc 89(11): 1525-1536.

98. Gadallah MA, Aboul Fotouh AM, Habil IS, Imam SS, Wassef G (2014) Surveillance of health care-associated infections in a tertiary hospital neonatal intensive care unit in Egypt: 1-year follow-up Am J Infect Control 42(11): 1207-1211.

99. Flores JC, Riquelme P, Cerda J, Carrillo D, Matus MS, et al. (2014) Higher risk for health care associated infections in hospitalized children with special health needs. Rev Chilena Infectol 31(3): 287292.

100. Cherkaoui S, Lamchahab M, Samira H, Zerouali K, Madani A, et al. (2014) Healthcare-associated infections in a paediatric haematology/ oncology unit in Morocco. Sante Publique 26(2): 199-204.

101. Kawanishi F, Yoshinaga M, Morita M, Shibata Y, Yamada T, et al. (2014) Risk factors for ventilator-associated pneumonia in neonata intensive care unit patients. J Infect Chemother 20(10): 627-630.

102. Turcotte RF, Brozovich A, Corda R, Demmer RT, Biagas KV, et al. (2014) Health care-associated infections in children after cardiac surgery. Pediatr Cardiol 35(8): 1448-55.
103. Wójkowska-Mach J, Gulczyńska E, Nowiczewski M, BorszewskaKornacka M, Domańska J, et al. (2014) Late-onset bloodstream infections of Very-Low-Birth-Weight infants: data from the Polish Neonatology Surveillance Network in 2009-2011. BMC Infect Dis 14 339.

104. Balasubramanian P, Tullu MS (2014) Study of ventilator-associated pneumonia in a pediatric intensive care unit. Indian J Pediatr 81(11): 1182-1186

105. Sathyendran V, McAuliffe GN, Swager T, Freeman JT, Taylor SL, et al. (2014) Clostridium difficile as a cause of healthcare-associated diarrhoea among children in Auckland, New Zealand: clinical and molecular epidemiology. Eur J Clin Microbiol Infect Dis 33(10): 17411747.

106. Barriga J, Cerda J, Abarca K, Ferrés M, Fajuri P, et al. (2014) Nosocomial infections after cardiac surgery in infants and children with congenital heart disease. Rev Chilena Infectol 31(1): 16-20.

107. Jiang N, Wang Y, Wang Q Li H, Mai J, et al. (2014) Clinical analysis of nosocomial infection and risk factors of extremely premature infants. Zhonghua Er Ke Za Zhi 52(2): 137-141.

108. Wolkewitz M, Cooper BS, Palomar-Martinez M, Alvarez-Lerma F, Olaechea-Astigarraga P, (2014) Multilevel competing risk models to evaluate the risk of nosocomial infection. Crit Care 18(2): R64.

109. da Silva NS, Muniz VD, Estofolete CF, Furtado GH, Rubio FG (2014) Identification of temporal clusters and risk factors of bacteremia by nosocomial vancomycin-resistant enterococci. Am J Infect Control 42(4): 389-392.

110. Ağın H, Devrim I, Ișgüder R, Karaarslan U, Kanık E, et al. (2014) Risk factors for candidemia in pediatric intensive care unit patients. Indian J Pediatr 81(11): 1158-1162.

111. Samuelsson A, Isaksson B, Hanberger H, Olhager E (2014) Lateonset neonatal sepsis, risk factors and interventions: an analysis of recurrent outbreaks of Serratia marcescens, 2006-2011. J Hosp Infect 86(1): 57-63.

112. Patria MF, Chidini G, Ughi L, Montani C, Prandi E, et al. (2013) Ventilator-associated pneumonia in an Italian pediatric intensive care unit: a prospective study. World J Pediatr 9(4): 365-368.

113. Klatte JM, Newland JG, Jackson MA (2013) Incidence, classification and risk stratification for Candida central line-associated bloodstream infections in pediatric patients at a tertiary care children's hospital, 2000-2010. Infect Control Hosp Epidemiol 34(12): 1266-1271.

114. Göçmez C, Çelik F, Tekin R, Kamaşak K, Turan Y, et al. (2014) Evaluation of risk factors affecting hospital-acquired infections in the neurosurgery intensive care unit. Int J Neurosci 124(7): 503-508.

115. Casolari C, Pecorari M, Della Casa E, Cattani S, Venturelli C, et al (2013) Serratia marcescens in a neonatal intensive care unit: two long-term multiclone outbreaks in a 10 -year observational study. New Microbiol 36(4): 373-383.

116. Naidoo R, Nuttall J, Whitelaw A, Eley B (2013) Epidemiology of Staphylococcus aureus bacteraemia at a tertiary children's hospital in Cape Town, South Africa. PLoS One 8(10): e78396.

117. Hoffmann-Santos HD, Paula CR, Yamamoto AC, Tadano T, Hahn RC (2013) Six-year trend analysis of nosocomial candidemia and risk factors in two intensive care hospitals in Mato Grosso, midwest region of Brazil. Mycopathologia 176(5-6): 409-415.

118. DalBen MF, Basso M, Garcia CP, Costa SF, Toscano CM, et al (2013) Colonization pressure as a risk factor for colonization by multiresistant Acinetobacter spp and carbapenem-resistant Pseudomonas aeruginosa in an intensive care unit. Clinics (Sao Paulo). 68(8): 1128-1133.

119. Tröger B, Göpel W, Faust K, Müller T, Jorch G, et al. (2014) Risk for late-onset blood-culture proven sepsis in very-low-birth weight infants born small for gestational age: a large multicenter study from the German Neonatal Network. Pediatr Infect Dis J 33(3): 238-243. 
120. Mação P, Lopes JC, Oliveira H, Oliveira G, Rodrigues F (2013) [Health care associated multidrug-resistant bacteria in a pediatric hospital: five year experience]. Acta Med Port 26(4):385-391.

121. Uchino M, Ikeuchi $\mathrm{H}$, Matsuoka H, Bando T, Ichiki $\mathrm{K}$, et al. (2014) Catheter-associated bloodstream infection after bowel surgery in patients with inflammatory bowel disease. Surg Today 44(4): 677684.

122. Rosanova MT, Stamboulian D, Lede R (2013) Infections in burned children: epidemiological analysis and risk factors. Arch Argent Pediatr 111(4): 303-308.

123. Seligman R, Ramos-Lima LF, Oliveira Vdo A, Sanvicente C, Sartori J, et al. (2013) Risk factors for infection with multidrug-resistant bacteria in non-ventilated patients with hospital-acquired pneumonia. J Bras Pneumol 39(3): 339-348.

124. Saleem AF, Qamar FN, Shahzad H, Qadir M, Zaidi AK (2013) Trends in antibiotic susceptibility and incidence of late-onset Klebsiella pneumoniae neonatal sepsis over a six-year period in a neonatal intensive care unit in Karachi, Pakistan. Int J Infect Dis 17(11): e9615.

125. Schaumburg F, Alabi A, Kokou C, Grobusch MP, Köck R, et al. (2013) High burden of extended-spectrum $\beta$-lactamase-producing Enterobacteriaceae in Gabon. J Antimicrob Chemother 68(9): 21402143.

126. Melzer M, Welch C (2013) Outcomes in UK patients with hospitalacquired bacteraemia and the risk of catheter-associated urinary tract infections. Postgrad Med J 89(1052): 329-334.

127. Jiménez JN, Ocampo AM, Vanegas JM, Rodriguez EA, Mediavilla JR, et al. (2013) A comparison of methicillin-resistant and methicillin-susceptible Staphylococcus aureus reveals no clinical and epidemiological but molecular differences. Int J Med Microbiol 303(2): 76-83.

128. Adamson V, Mitt P, Pisarev H, Metsvaht T, Telling K, et al. (2012) Prolonged outbreak of Serratia marcescens in Tartu University Hospital: a case-control study. BMC Infect Dis 12: 281.

129. Afjeh SA, Sabzehei MK, Karimi A, Shiva F, Shamshiri AR (2012) Surveillance of ventilator-associated pneumonia in a neonatal intensive care unit: characteristics, risk factors, and outcome. Arch Iran Med 15(9): 567-571.

130. Bolat F, Uslu S, Bolat G, Comert S, Can E, et al. (2012) Healthcareassociated infections in a Neonatal Intensive Care Unit in Turkey. Indian Pediatr 49(12): 951-957.

131. Cernada M, Aguar M, Brugada M, Gutiérrez A, López JL, et al. (2013) Ventilator-associated pneumonia in newborn infants diagnosed with an invasive bronchoalveolar lavage technique: a prospective observational study. Pediatr Crit Care Med 14(1): 55-61.

132. Porto JP, Mantese OC, Arantes A, Freitas C, Gontijo Filho PP, et al (2012) Nosocomial infections in a pediatric intensive care unit of a developing country: NHSN surveillance. Rev Soc Bras Med Trop 45(4): 475-479.

133. Fekih A, Ben S, Raddaoui K, Askri A, Trifa M (2012) [Risk factors for nosocomial infection in pediatric burn patients]. Ann Fr Anesth Reanim 31(7-8): 591-595.

134. Siddiqui NU, Wali R, Haque AU, Fadoo Z (2012) Healthcare-associated infections among pediatric oncology patients in Pakistan: risk factors and outcome. J Infect Dev Ctries 6(5): 416-421.

135. Dotis J, Prasad PA, Zaoutis T, Roilides E (2012) Epidemiology, risk factors and outcome of Candida parapsilosis bloodstream infection in children. Pediatr Infect Dis J 31(6): 557-560.

136. Siedelman L, Kline S, Duval S (2012) Risk factors for community- and health facility-acquired extended-spectrum $\beta$-lactamase-producing bacterial infections in patients at the University of Minnesota Medical Center, Fairview. Am J Infect Control 40(9): 849-853.

137. Akeme Y, de Paula CR, Dias LB, Tadano T, Martins ÉR, et al. (2012) Epidemiological and clinical characteristics of nosocomial candidiasis in university hospitals in Cuiabá--Mato Grosso, Brazil. Rev Iberoam Micol 29(3): 164-168.

138. Maltezou HC, Tryfinopoulou K, Katerelos P, Ftika L, Pappa O, et al. (2012) Consecutive Serratia marcescens multiclone outbreaks in a neonatal intensive care unit. Am J Infect Control 40(7): 637-642.

139. Alp E, Coruh A, Gunay GK, Yontar Y, Doganay M (2012) Risk factors for nosocomial infection and mortality in burn patients: 10 years of experience at a university hospital. J Burn Care Res 33(3): 379-385.

140. García J, Arriourtúa AB, Torre JA, Antón JG, Vicente JC, et al. (2014) [A national multicentre study on nosocomial infections in PICU]. An Pediatr (Barc) 80(1): 28-33.

141. Dotis J, Prasad PA, Zaoutis T, Roilides E (2012) Epidemiology, risk factors and outcome of Candida parapsilosis bloodstream infection in children. Pediatr Infect Dis J 31(6): 557-560.

142. Leighton P, Cortina-Borja M, Millar M, Kempley S, Gilbert R (2012) Risk-adjusted comparisons of bloodstream infection rates in neonatal intensive-care units. Clin Microbiol Infect 18(12): 12061211.

143. Infecciones asociadas a la Atención en Salud (HAI) (2013) Y Resistencia antimicrobiana. Programa Nacional de Promoción, Prevención Vigilancia y Control. Ministerio de Salud.

144. Cabrera J, Holder R, Pardo P, Stempiluk V (2013) Vigilacia Epidemiológica de las Infecciones Asociadas a la Atención de la Salud. Organización Panamerican de la Salud. Disponible.

145. Instituto Nacional de Salud (2015) Protocolo de Vigilancia en Salud Pública. Infecciones Asociadas a Dispositivos. INS 26-45.

146. Ministerio de Salud de la Nación de Argentina (2013) Programa Nacional de Epidemiología y Control de Infecciones Hospitalarias (VIHDA). [Fecha de consulta: mayo 28 de 2013].

147. Ministerio de Salud de Chile. Infecciones Intrahospitalarias y asociadas a la atención en Salud.

148. Ministerio de Salud Pública de Uruguay (2013) Control de infecciones intrahospitalarias.

149. Rosenthal VD, Maki DG, Salomao R, Moreno CA, Mehta Y, et al. (2006) Device-associated nosocomial infections in 55 intensive care units of 8 developing countries. Ann Intern Med 145(8): 582-591.

150. Schmunis GA, Gordillo A, Acosta-Gnass S, Bologna R, Ruvinsky S, et al. (2008) Costo de la infección nosocomial en unidades de cuidados intensivos de cinco países de América Latina: llamada de atención para el personal de salud. Rev Panam Infectol 10(4 Supl 1): S70-S77.

151. Ministerio de Salud y Protección Social (2012) Circular 045: Implementación de la estrategia de vigilancia en salud pública de infecciones asociadas a la atención en salud- HAI, Resistencia y consumo de antmiccrobianos.

152. Ministerio de Salud y Protección Social. Circular 045 del 2012 Implementación de las estrategias e vigilancia de Infecciones Asociadas a la Atención en Salud, Resistencia y Consumo de Antibióticos.

153. Secretaria Distrital de Salud. Boletín Epidemiológico de Resistencia Bacteriana.

154. Maldonado N, Villamil MAL, Velásquez VL, Robledo J, Robledo RCG (2013) Caracterización de los programas de prevención y control de infecciones en instituciones hospitalarias de Medellín -Colombia, 2011. En Infect 17(3): 136-145.

155. Política de prevención, control y vigilancia epidemiológica de infecciones intrahospitalaria (IIH) para Bogotá, D.C. Secretaría Distrital de Salud de Bogotá D.C - Dirección de Salud Pública. 2007

156. Observatorio de la calidad de Atención en Salud http:// calidadensalud.minsalud.gov.co/IndicadoresdeCalidad/Resultados/ IndicadoresdeIPSparaDTS.aspx (consultado el 11 de noviembre de 2014).

157. Secretaría Distrital de Salud. Boletín epidemiológico distrital de 
infecciones intrahospitalarias año 2007. Publicación Secretaría Distrital de Salud. [En línea] Bogotá 2009. [Fecha de acceso noviembre 05 de 2009]. URL: disponible en: http://www. saludcapital.gov.co/ ListasVsp/IIH/Boletines/ Boletin_IIH.pdf

158. Instituto Nacional de Salud.

159. (2012) Ministerio de Salud y Protección Social. Circular 045: Implementación de la estrategia de vigilancia en salud pública de infecciones asociadas a la atención en salud- HAI, Resistencia y consumo de antmiccrobianos.

160. Secretaria Distrital de Salud (2010) Criterios Diagnósticos de Infecciones Asociadas al Cuidado de la Salud a ser utilizados para la notificación al subsistema de vigilancia epidemiológica de IACS en Bogotá DC, Colombia.

\section{Your next submission with Juniper Publishers} will reach you the below assets

- Quality Editorial service

- Swift Peer Review

- Reprints availability

- E-prints Service

- Manuscript Podcast for convenient understanding

- Global attainment for your research

- Manuscript accessibility in different formats

( Pdf, E-pub, Full Text, Audio)

- Unceasing customer service

Track the below URL for one-step submission https://juniperpublishers.com/online-submission.php 